\title{
PERUBAHAN ASAM ASETAT, TOTAL POLIFENOL DAN WARNA BIJI KAKAO ASALAN SELAMA FERMENTASI
}

\author{
Change of Acetic Acid, Total Polifenol and Color of Coconut Origin During \\ Fermentation \\ Mulono Apriyanto ${ }^{1}$, Hermiza Mardesci ${ }^{1}$, dan Rujiah ${ }^{2}$ \\ ${ }^{1}$ Prodi Teknologi Pangan, Universitas Islam Indragiri \\ JI. Propinsi parit 1 Tembilahan, INHII Riau \\ ${ }^{2}$ Dinas Tanaman Pangan Hortikultura dan Peternakan \\ Kabupaten Indragiri Hilir, Riau \\ e-mail: mulonopriyanto71@gmail.com
}

\begin{abstract}
Asalan cocoa beans are dried cocoa beans at the level of farmer in Samigaluh, Kulon Progo Regency, Yogyakarta, mostly produced without fermentation. The study aims to determine changes in acetic acid, total polyphenols and colour cocoa beans during fermentation. Fermentation is done in three methods; The control treatment, the second treatment was the addition of S.cerevisiae (FNCC3056), L.lactis (FNC0086) and A.aceti (FNCC0016) inoculum, respectively $10^{8}$ cfu/gram given simultaneously at the beginning of fermentation. The third treatment of inoculum addition gradually then all treatments were fermented for 120 hours. The results showed the percentage of brownish purple color, the total polyphenols of cocoa beans decreased, the results of control treatments, the addition of inoculum at the beginning of fermentation and the addition of inoculums gradually from 30.11 to $5.03 \%, 30.14-4.98 \%$ and $30.09-3.02 \%$ and the total polyphenols respectively from $0.17-0.08$, 0.18-0.07 and 0.17-0.06 meq gallic acid/gram. This study can be concluded that there was a change in acetic acid, the total polyphenols caused by changes in the percentage of brown color occurred more in the treatment of inoculum addition gradually.
\end{abstract}

Keywords: Asalan cocoa beans, fermentation, total polyphenols, and colour

Abstrak: Biji kakao asalan adalah biji kakao kering di tingkat petani di Samigaluh, Kabupaten Kulon Progo, Yogyakarta sebagian besar dihasilkan tanpa fermentasi. Kelemahan biji kakao kering tersebut yaitu tidak menghasilkan prekursor flavour khas kakao, sehingga upaya memiliki prekursor flavour khas kakao dilakukan melalui proses fermentasi. Penelitian ini bertujuan untuk mengetahui perubahan asam asetat, total polifenol dan warna biji kakao asalan selama fermentasi. Fermentasi dilakukan dengan tiga cara yaitu: Perlakuan kontrol, perlakuan kedua yaitu penambahan inokulum S.cerevisiae (FNCC3056), L.lactis (FNC0086) dan A.aceti (FNCC0016), masing-masing10 $0^{8}$ cfu/gram yang diberikan serentak pada awal fermentasi. Perlakuan ketiga, pemberian inokulum secara bertahap S.cerevisiae (FNCC3056) pada awal fermentasi, L.lactis (FNC0086) di awal 24 jam kedua dan A.aceti (FNCC0016) di 24 jam ketiga, kemudian seluruh perlakuan difermentasi selama 120 jam. Hasil penelitian menunjukan persentase warna ungu kecoklatan, total polifenol keping biji kakao mengalami penurunan, hasil perlakuan kontrol, penambahan inokulum di awal fermentasi dan penambahan inokulum secara bertahap berturut-turut dari 30,11-5,03\%, 30,14-4,98\% dan 30,09-3,02\% serta total polifenol berturut-turut dari 0,17-0,08; 0,18-0,07 dan 0,17-0,06 meq asam galat/gram. Penelitian ini dapat disimpulkan bahwa terjadi perubahan asam asetat, total polifenol memberikan akibat perubahan presentase warna coklat lebih banyak terjadi pada perlakuan penambahan inokulum secara bertahap.

Kata kunci: Biji kakao asalan, fermentasi, total polifenol dan, warna

\section{PENDAHULUAN}

Sebanyak 93\% kakao Indonesia dihasilkan oleh petani yang membudidayakan biji kakao hanya dengan mencuci dan mengeringkan matahari tanpa melalui proses fermentasi, sementara 7\% dihasilkan oleh sektor swasta atau perkebunan 
nasional dengan proses fermentasi (Apriyanto dan Rujiah, 2017).

Kakao fermentasi pada dasarnya adalah proses reformasi gula dan asam sitrat dalam pulp menjadi asam organik yang dilakukan oleh fermentasi mikroba (Camu et al., 2008). Asam organik akan menginduksi reaksi enzimatik yang ada di dalam biji, menyebabkan perubahan biokimia yang akan membentuk senyawa yang memberi rasa, rasa, dan warna dari biji kakao (Afoakwa et al., 2014). Proses ini dilakukan oleh biji berarti kakao dalam wadah tertutup selama 5-7 hari disertai pembalikan setiap 2 hari. Tanpa melalui proses fermentasi biji kakao akan terasa pahit, astringent, dan akan tidak memiliki aroma khas cokelat ketika diproses (Apriyanto dan Rujiah, 2017).

Pulp biji kakao telah kehilangan sebagian besar kandungan air. Kandungan air mempengaruhi pertumbuhan mikroba dalam pulp sehingga terjadi reaksi enzimatik dalam biji dan (Pasau, 2013). Air akan menyatukan enzim ke substrat yang ada di dalam biji sehingga hidrolisis dan oksidasi dari kandidat senyawa rasa, warna, dan aroma cocoa dapat terjadi. Kandungan air yang dibutuhkan dalam fermentasi kakao lebih dari 35\%. Substrat adalah bahan yang diangkut oleh mikroba selama fermentasi. Substrat dalam fermentasi biji kakao adalah gula dan asam sitrat yang terkandung dalam ampas. Proses fermentasi para pelaku fermentasi mikroba akan merombak pulp menjadi asam organik. Asam akan berdifusi ke dalam biji dan menginduksi reaksi enzimatik untuk membentuk senyawa dari kandidat aroma, aroma dan warna (Afoakwa et al., 2014). Berdasarkan hal di atas, perlu sekali mengembalikan kadar air biji kakao sebelum fermentasi.

Penelitian fermentasi biji kakao kering menggunakan non-fermentasi dilakukan di Laboratorium Teknologi Pangan, Universitas Islam Indragiri. Penelitian ini bertujuan untuk mengetahui perubahan asam asetat, total polifenol dan warna biji kakao asalan selama fermentasi.

\section{METODOLOGI \\ Pembuatan Biji Kakao}

Biji kakao digunakan diambil dari buah kakao matang, yang merupakan buah yang kuning atau oranye, ketika digerakkan akan menimbulkan bunyi. Buah kakao dibelah kemudian biji tanpa dicuci, selanjutnya biji dikeringkan dalam lemari pengering dengan suhu 40 ${ }^{\circ} \mathrm{C}$ sampai kadar air hingga 15\%. 100 gram kakao kering direndam dalam air $60 \mathrm{~mL}$ kemudian difermentasi selama 5 hari (120 jam) secara spontan pada suhu kamar dan diamati perubahan yang terjadi terhadap asam asetat, total polifenol dan warna biji kakao asalan selama fermentasi.

\section{Persiapan Sampel Ampas}

Pulp dipisahkan dari biji dengan memasukan biji segar kedalam kantong kemudian kantung berisi biji diremas remas sampai pulp terlepas dari biji.

\section{Biji Kakao Fermentasi Terfermentasi}

Sejumlah biji kakao dijemur sinar matahari, kemudian sebanyak 100 gram/gelas jar biji kakao kering difermentasi. Biji kakao direndam air dalam botol kaca dengan volume air 60 $\mathrm{mL}$ selama 1 jam, kemudian difermentasi pada suhu kamar selama 5 hari.

\section{Metode Desain Fermentasi Apriyanto et al (2016a) dengan sedikit modifikasi}

Teknik pertama, biji kakao rehidrasi yang dipilih dari Tahap I difermentasi secara spontan (tanpa inokulum) sebagai perlakuan kontrol.Teknik fermentasi kedua adalah penambahan inokulum ragi $S$. cerevisiae (FNCC 3056), L. lactis (FNC 0086) dan $A$. aceti (FNCC0016) secara bersamaan pada awal 24 jam pertama. Perlakuan fermentasi ini selanjutnya disebut penambahan inokulum mikroba secara bersamaan (IA). Teknik fermentasi ketiga mirip dengan yang kedua, tetapi penambahan inokulum secara bertahap, menambahkan inokulum ragi pada awal 24 jam pertama, BAL pada awal 24 jam kedua, BAA pada awal 24 jam ketiga. 
Perlakuan ketiga ini selanjutnya disebut inokulasi mikroba bertahap (IB). Sebuah teknik II fermentasi menggunakan waktu fermentasi total 120 jam (5x24 jam) dengan pengaturan suhu $35^{\circ} \pm 0,1^{\circ} \mathrm{C}$ pada awal 24 jam pertama, $45^{\circ} \pm 0,1^{\circ} \mathrm{C}$ pada awal kedua 24 jam, $55^{\circ} \pm 0,1{ }^{\circ} \mathrm{C}$ pada awal 24 jam dan $35^{\circ}+0,1^{\circ} \mathrm{C}$ pada awal 48 jam terakhir.

\section{Total Polifenol}

Penentuan total polifenol mengacu metode Folin-Ciocalteu dengan cara kerja sebagai berikut: $1 \mathrm{ml}$ ekstrak dipipet dan dimasukan dalam labu takar $10 \mathrm{ml}$, selanjutnya diencerkan aquades sampai volume tepat $10 \mathrm{~mL}$. Ekstrak polifenol kemudian direaksikan dengan $0,5 \mathrm{ml}$ reagen Folin-Ciocalteu (1 bagian sampel:1 bagian air) dan dibiarkan selama 2-3 menit. Setelah 2-3 menit sampel ditambah $1 \mathrm{~mL}$ natrium karbonat $15 \%$ (15 gram natrium karbonat dilarutkan dengan aquades sampai volume tepat $100 \mathrm{~mL}$ ), agar warna menjadi stabil pembentukan warna. Pembentukan warna biru pada sampel berlangsung sedikitnya sekitarnya 2 jam. Sampel kemudian diukur absorbansinya dengan menggunakan spektrofotometer pada panjang gelombang $760 \mathrm{~nm}$.

Total polifenol dinyatakan dalam $\mathrm{mg}$ asam galat ekuivalen/gram sampel, dan dihitung berdasarkan persamaan kurva standar larutan asam galat dengan kisaran konsentrasi 1-100 mg/L (ppm).

\section{Analisis Warna Biji (Cut Test)}

Tes ini dilakukan dengan mengamati perubahan warna visual dan subjektif. Ambil sampel 50 item biji kakao kering dari fermentasi (random sampling). Biji kakao dipotong secara longitudinal dengan pisau pemotong dan biji belah yang diamati satu per satu untuk menentukan kondisi biji kakao seperti biji kakao, biji kecoklatan ungu dan biji-biji licin. Informasi tentang karakteristik benih uji warna dari potongan biji adalah:

1. Biji kakao yang tidak difermentasikan disebut biji-biji licin yang ditunjukkan oleh setengah atau lebih dari permukaan irisan biji keabu-abuan seperti batu tulis atau biru keabuabuan dan memiliki tekstur padat dan padat.

2. Di bawah biji yang difermentasi adalah biji yang tidak difermentasi dan menunjukkan $3 / 4$ atau lebih banyak permukaan irisan biji ungu yang memiliki tekstur padat dan padat.

3. Biji fermentasi adalah biji kakao yang memiliki semua keping coklat.

\section{HASIL DAN PEMBAHASAN}

Hasil penelitian menunjukkan bahwa total polifenol biji kakao turun pada seluruh perlakuan seperti yang ditunjukkan pada Gambar 1. Hasil menunjukkan bahwa warna gradasi biji kakao asalan selama fermentasi semua perlakuan yang disajikan dalam Tabel 1 .

Tabel 1. Hasil Analisis Statistik Perubahan Warna Keping Biji

\begin{tabular}{lccc}
\hline \multicolumn{1}{c}{ Parameter } & \multicolumn{3}{c}{ Perlakuan } \\
\cline { 2 - 4 } & kontrol & IA & IB \\
Warna keping biji (\%) : & $40,15 \pm 0,20 \mathrm{~b}$ & $22,19 \pm 0,56 \mathrm{a}$ & $17,78 \pm 0,15 \mathrm{a}$ \\
Slaty (kehitaman) & $25,49 \pm 0,43 \mathrm{a}$ & $20,25 \pm 0,86 \mathrm{a}$ & $17,70 \pm 0,83 \mathrm{a}$ \\
Ungu kecoklatan & $34,36 \pm 0,15 \mathrm{a}$ & $57,56 \pm 0,80 \mathrm{a}$ & $64,52 \pm 0,39 \mathrm{a}$ \\
Coklat & \multicolumn{3}{c}{ Huruf berbeda di belakang angka pada baris sama menunjukan } \\
\hline Keterangan : & $\begin{array}{l}\text { beda nyata } \leq 0,05 \text {. Hasil rata-rata 2 ulangan dengan 3 ulangan } \\
\text { analisis }\end{array}$ & &
\end{tabular}




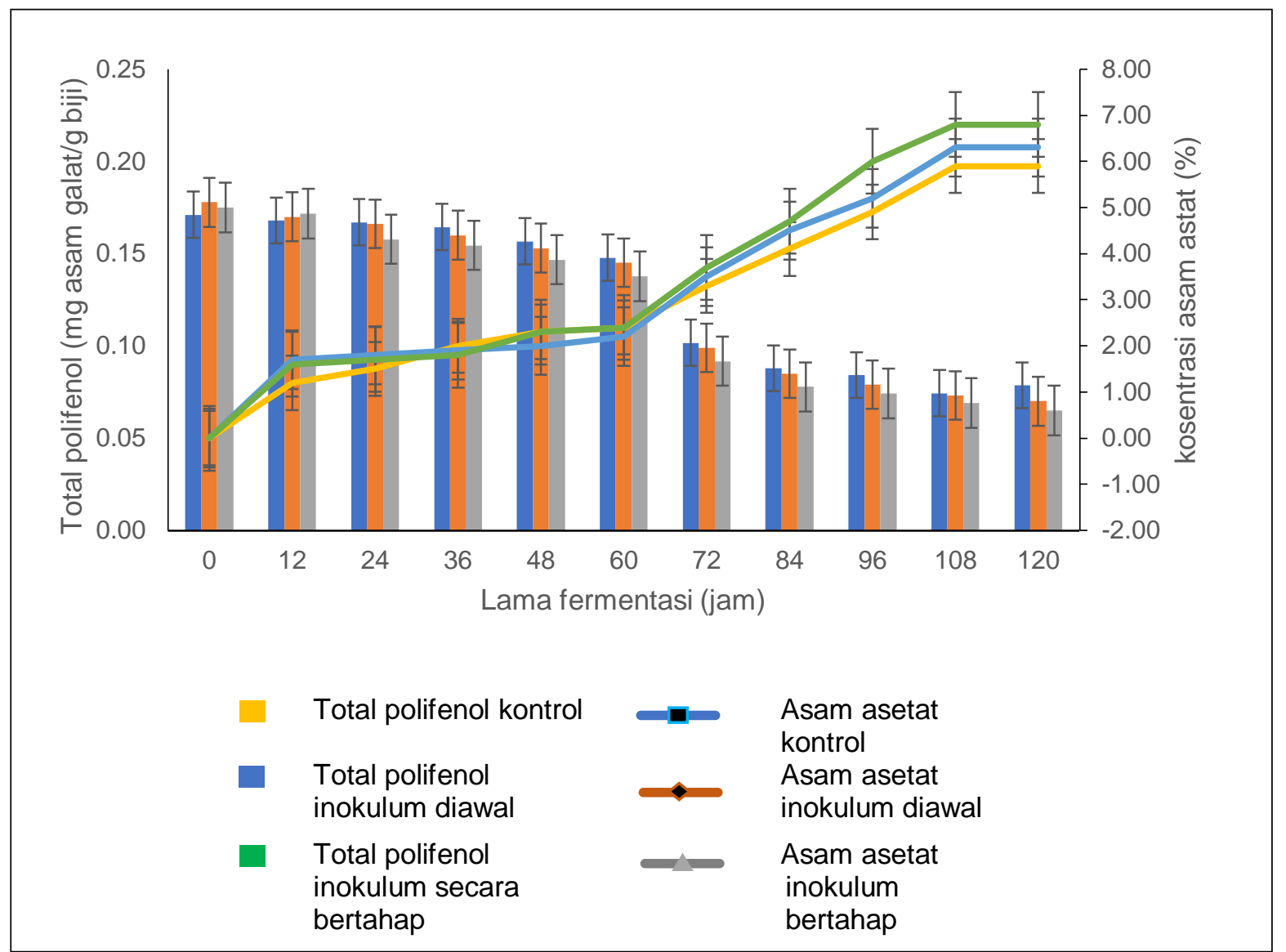

Gambar 1. Hubungan kosentrasi asam asetat terhadap perubahan total polifenol biji kakao hasil perlakuan kontrol, penambahan inokulum secara serentak dan secara bertahap

\section{Gradasi Warna Biji Kakao}

Hasil analisis statistik dengan ANOVA satu arah menunjukkan bahwa ada pengaruh penambahan inokulum untuk perubahan warna dari biji kakao. Tabel 1 terlihat hasil analisis statistik ANOVA satu arah menunjukkan bahwa variasi dalam teknik fermentasi memiliki efek pada perubahan warna potongan coklat kering. Persentase warna coklat biji kakao kering antara perlakuan kontrol dan penambahan inokulum secara simultan menunjukkan perbedaan yang signifikan. Rata-rata warna slaty dari biji kakao kering dalam kontrol, IA dan pengobatan IB adalah $40,15,22,19$, dan $17,78 \%$ masingmasing. Persentase warna slaty dari perlakuan kontrol, IA dan biji kakao IB menunjukkan bahwa dari $65 \%$ menjadi 20,53, 0, dan $0 \%$ masing-masing pada 120 jam fermentasi sejalan dengan penelitian Apriyanto et al. (2016b), Apriyanto et al. (2016c) dan Owusu (2010).

Warna kecoklatan-ungu dari potongan biji kako kering antara perlakuan tidak menunjukkan perbedaan yang signifikan $(p<0.05)$. Warna coklat kecoklatan rata-rata biji kakao dikontrol, penambahan inokulum secara simultan dan bertahap berturutturut yaitu 25.49, 20.25, dan $17.70 \%$. Persentase potongan coklat kecoklatan dari biji kakao kering pada awal perlakuan kontrol, IA dan IB masingmasing adalah $30,11,30,13$, dan $30,09 \%$. Persentase kontrol ungu kecoklatan, IA dan IB menunjukkan penurunan berturut-turut yaitu 5,03, 4,98 , dan $3,02 \%$ pada akhir fermentasi sejalan dengan penelitian Apriyanto et al (2016b), Apriyanto et al., (2016c) dan Ganda et al., (2008). 
Warna coklat dari biji kakao diperlakukan dengan kontrol, penambahan inokulum secara bersamaan dan bertahap menunjukkan bahwa tidak ada perbedaan antara 0,05. Potongan biji berwarna coklat rata-rata dikontrol, penambahan inokulum secara bersamaan dan bertahap adalah 34,36 , 57,56 , dan $64,52 \%$ masing-masing. Persentase potongan biji cokelat dikontrol, penambahan inokulum secara simultan dan bertahap pada awal fermentasi adalah 5,02, 5,02, dan 5,01\% masing-masing

menunjukkan peningkatan pada akhir fermentasi, 70,01, 95,03, dan 97,01\%. Kegagalan untuk mencapai suhu kematian biji menyebabkan ketidakefektifan enzim endogen sehingga perubahan warna biji-bijian menjadi coklat tidak terjadi. Sejalan dengan penelitian Apriyanto et al. (2016a), Apriyanto et al (2016b), Apriyanto et al., (2016c) dan Moreira et all (2013). Perubahan warna biji kakao selama fermentasi tersaji pada Gambar 2.

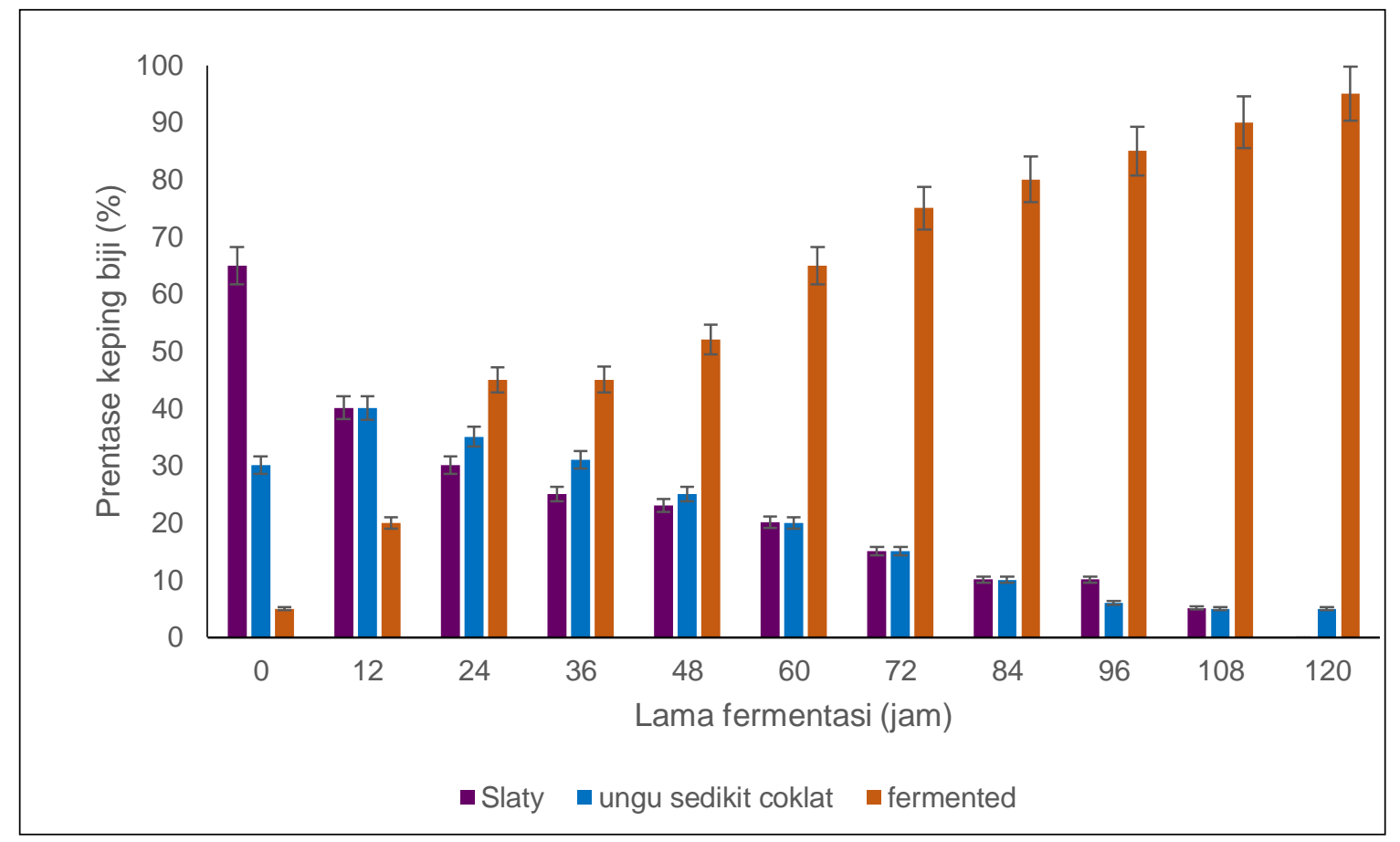

Gambar 2. Persentase Perubahan Warna Keping Biji Kakao Selama Fermentasi Hasil Perlakuan Kontrol, IA Dan IB. Awal (0)-24 Jam Fermentasi Suhu Inkubator $35^{\circ} \mathrm{C}, 24-48$ jam fermentasi suhu inkubator $45^{\circ} \mathrm{C}, 48-72$ jam fermentasi suhu inkubator $55^{\circ} \mathrm{C}$ dan $72-120$ jam fermentasi suhu inkubator $35^{\circ} \mathrm{C}$.

Dalam perlakuan bertahap $S$. cerevisiae untuk merombak gula dalam pulp lebih banyak sehingga produksi etanol lebih banyak dan pada waktu yang tepat etanol diubah menjadi asam asetat oleh $A$. acetic dimana reaksi reformasi etanol menjadi asam asetat juga menghasilkan panas yang menyebabkan suhu fermentasi meningkat. Penambahan inokulum secara bersamaan menghasilkan suhu kematian biji tidak tercapai, dapat diprediksi bahwa persaingan antara $S$. cereviceae dan $L$. lactis terjadi. Sejalan dengan penelitian Apriyanto, et al.,(2016a), Apriyanto et al (2016b), Apriyanto et al., (2016c) dan Pasau, (2013).

Selain itu, antosianin sebagai hasil hidrolisis polifenol dapat mengubah warna benih menjadi ungu, sedangkan jika oksidasi senyawa tannin oleh enzim polifenoloksidase menghasilkan pembentukan warna coklat pada biji sejalan dengan penelitian Widianto et al., (2013). 
Total Polifenol dari Biji Kakao Selama Fermentasi

Hubungan antara konsentrasi asam asetat terhadap perubahan polifenol selama fermentasi disajikan pada Gambar 1. Hasil penelitian ini menunjukkan bahwa perubahan konsentrasi asam asetat berkebalikan dengan penurunan polifenol. Asam asetat adalah asam organik yang berdifusi ke dalam potongan biji yang mengakibatkan aktivasi polifenol enzim oksidase yang mengoksidasi polifenol. Pada 72 jam fermentasi, total polifenol perlakuan, IA dan IB masing-masing adalah 0,102, 0,099, dan 0,092 mg asam galat/g, dengan konsentrasi asam asetat masing-masing, 3,46, 3,53, dan $3,32 \%$. Pada 108 jam fermentasi, konsentrasi asam asetat dalam kontrol, IA dan IB menunjukkan konsentrasi tertinggi masing-masing 5,94, 6,31, dan $6,83 \%$.

Pada jam ke 108 total polifenol dalam perlakuan kontrol, penambahan inokulum secara serentak dan secara bertahap menunjukkan nilai terendah berturut-turut yaitu $0,074,0,073$, dan 0,066 ( $\mathrm{mg}$ asam galat/g). Penurunan total polifenol dan peningkatan konsentrasi asam asetat yang dihasilkan sesuai dengan hasil penelitian yang diperoleh Kustyawati dan Setyani (2012) dan Apriyanto et al., (2017), yang telah mempelajari penambahan $S$. cerevisiae, $L$. lactis dan $A$. aceti inokulum mikroba untuk fermentasi varietas segar biji kakao segar. Penurunan total polifenol selama fermentasi dapat dianggap disebabkan oleh oksidasi aktivitas enzimatik dan non-enzimatik setelah kematian biji sejalan dengan penelitian Camu et al., (2008), Campos et al., (2012) dan Campos et al., (2011). Hasil penelitian ini konsisten dengan hasil yang diperoleh oleh Misnawi et al., (2002) yang mempelajari aktivitas enzim dalam biji kakao kering pada pembentukan prekursor (Jinap et al. 1994 ).

\section{SIMPULAN}

Kualitas biji kakao yang difermentasi dapat ditingkatkan melalui proses fermentasi yang terkontrol. Perlakuan penambahan inokulum secara bertahap selama fermentasi dapat meningkatkan suhu fermentasi $\left(51^{\circ} \mathrm{C}\right)$, persentase jumlah potongan biji coklat $(97,01 \%)$, konsentrasi asam asetat $(6,83 \%)$, dibandingkan dengan perlakuan kontrol dan penambahan inokulum secara bersamaan. Pengobatan penambahan inokulum secara bertahap dapat mengurangi kandungan polifenol.

\section{DAFTAR PUSTAKA}

1. Apriyanto Mulono, 2016a, Changes in Chemical Properties of Dreid Cocoa (Theobroma cacao) Beans during Fermentation,. Intl. J. Food. Ferment. 5(1): 11-16.

2. Apriyanto Mulono, Sutardi, Eni Harmayani dan Supriyanto, 2016b. Study on effect of fermentation to the quality parameter of cocoa bean in Indonesia, Asian J. Dairy \& Food Res., 35 (2) : 160-163.

3. Apriyanto M, Sutardi, Eni Harmayani dan Supriyanto, 2016c, Perbaikan Proses Fermentasi Biji Kakao Non Fermentasi dengan Penambahan Biakan Murni Saccharomyces cerevisiae, Lactobacillus lactis, dan Acetobacter aceti, AGRITECH, Vol. 36, No. 4, hal 410-415.

4. Apriyanto Mulono dan Rujiah. 2017. Penurunan total polifenol, etanol, asam laktat, asam asetat, dan asam amino selama fermentasi biji kakao asalan dengan penambahan inokulum. Jurnal Gizi dan Dietetik Indonesia Vol. 5, No. 1 hal 1-8

5. Apriyanto Mulono, Sutardi, Supriyanto, Eni Harmayani, Fermentasi Biji Kakao Kering menggunakan Saccharomyces cerevisiae, Lactobacillus lactis, dan Acetobacter aceti, AGRITECH, Vol 37. No 3. hal $302-311$

6. Afoakwa, E. O., Budu, A. S., Mensahbrown, H., dan Felix, J. 2014. Changes in Biochemical and Physicochemical Qualities during Drying of Pulp Preconditioned and Fermented Cocoa (Theobroma cacao) Beans. Internasional Food Research Journal. Afoakwa, Emmanuel Ohene., Kongor, J.E., Takrama, J. Badudu, A. S. (2013). Changes in nib acidification and biochemical composition during 
fermentation of pulp pre-conditioned cocoa (Theobroma cacao) beans. Internasional Food Research Journal, 20(4), 1843-1853.

7. Campos, R. J., Escalona-Buendia, H.B, Avila, O.I., Cervantes, L.E dan Jamramillo-Flores, M.E. 2011. Dynamic of Volatile and Non Volatile compound in cocoa (theobroma cacao L) during Fermentation and Drying Proses Using Principal Component Alaysis. Food Research International. 44: 250-258

8. Campos, R. J., Escalona-Buendía, H. B., Ramos.E.H.B., Avila, C.S.M,, Flores, O.I. J.E., dan Cervantes, L.E. 2012. Effect of fermentation time and drying temperature on volatile compounds in cocoa. Food Chemistry, 132(1):277-288.

9. Camu, NicholasCamu, N., Winter, T. De, Addo, S. K., Takrama, J. S., Bernaert, H., \& Vuyst, L. De. 2008. Fermentation of cocoa beans: influence of microbial

10. Ganda Putra, G.P., Harjiono, Susanto, T., Kumalaningsih, S., dan Aulanni'am. 2008. Optimasi kondisi depolimerisasi pulp biji kakao oleh enzim poligalakturonase endojinus. Jurnal Teknik Industri. 9(1): I24-34

11. Jinap, S., Thien, J dan Yap, T.N., 1994. Effect of Drying on Acidity and Volatile Fatty Acids Content of Cocoa Benas. Journal of The Science of Food and Agriculture. 65:67-75

12. Kustyawati, ME dan Setyani, S. 2012. Pengaruh penambahan inokulum campuran terhadap perubahan kimia dan mikrobiologi selama fermentasi coklat, 13(2), 73-84
Chocolate, Ph.D. Thesis. Faculty of Life Science, University of Cophenhagen. Denmark

14. Misnawi., Jinap, S., Nazamid, S., dan Jamilah, B., 2002. Activation of remaining key enzymes in dried underfermented cocoa beans and its effect on aroma precursor formation. Food Chemistry. 78(4):407-417. Available at: http://linkinghub.elsevier.com/retrieve/pi $\mathrm{i} / \mathrm{S} 0308814602001206$

15. Moreira, I. M. D. V., Miguel, M. G. D. C. P., Duarte, W. F., Dias, D. R., dan Schwan, R. F. 2013. Microbial succession and the dynamics of metabolites and sugars during the fermentation of three different cocoa (Theobroma cacao L.) hybrids. Food Research International, 54(1), 9-17. http://doi.org/10.1016/j.foodres.20 13.06.001.

16. Pasau, C. 2013. Efektivitas penggunaan asam asetat pada pemeraman biji kakao segar analog fermentasi. E-J.Agrotekbis, 1(2):113-120

17. Widianto, D., Pramita, A. D., dan Wedhastri, S., 2013. Perbaikan proses fermentasi biji kakao kering dengan penambahan tetes tebu, khamir, dan bakteri asam, Jurnal Tekno sains. $3(1): 1-80$.

13. Owusu, 2010. Influence of Raw Material and Processig on Aroma in 